\title{
Off-Site Construction of Concrete Housing in the Andean Region: Advantages and Disadvantages
}

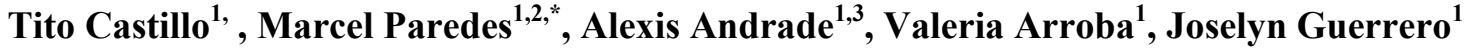 \\ ${ }^{1}$ Faculty of Engineering, Universidad Nacional de Chimborazo, Ecuador \\ ${ }^{2}$ Technical School of Industrial Engineering, Universidad Politécnica de Madrid, Spain \\ ${ }^{3}$ Higher Technical School of Civil Engineering, Canals and Ports, Universitat Politécnica de Valéncia, Spain
}

Received October 5, 2021; Revised January 3, 2022; Accepted January 16, 2022

\section{Cite This Paper in the following Citation Styles}

(a): [1] Tito Castillo, Marcel Paredes, Alexis Andrade, Valeria Arroba, Joselyn Guerrero , "Off-Site Construction of Concrete Housing in the Andean Region: Advantages and Disadvantages," Civil Engineering and Architecture, Vol. 10, No. 2, pp. 477-489, 2022. DOI: 10.13189/cea.2022.100208.

(b): Tito Castillo, Marcel Paredes, Alexis Andrade, Valeria Arroba, Joselyn Guerrero (2022). Off-Site Construction of Concrete Housing in the Andean Region: Advantages and Disadvantages. Civil Engineering and Architecture, 10(2), 477-489. DOI: 10.13189/cea.2022.100208.

Copyright $\bigcirc 2022$ by authors, all rights reserved. Authors agree that this article remains permanently open access under the terms of the Creative Commons Attribution License 4.0 International License

\begin{abstract}
The construction of prefabricated houses is a viable option to solve the problems of housing demand in the Andean region. The prefabricated concrete houses have been built in several countries in the region and will surely be developed in the future. Thinking about their constructability, information is required about this construction system, which is scarcely known by the main people involved in construction: governments, users and builders. The present work seeks to fill the knowledge gap on the production and assembly of prefabricated concrete housing $(\mathrm{PFCH})$, as well as on its advantages and disadvantages. For this purpose, a search for providers of this type of housing was carried out in Argentina, Bolivia, Colombia, Chile, Ecuador and Peru. Through an analysis of documentary information and interviews with the managers of the supplier companies, it was established that one of the main aspects in this construction system is the definition of the constituent elements of the house as this defines the need for equipment and hand of work for its assembly. The main advantage is the short execution time, while among the disadvantages is the poor adaptability of the designs. There are conflicting opinions as to whether its cost is an advantage. This research contributes to the constructability of PFCH in the Andean region, facilitating knowledge that can be integrated in the design and in the construction stage in order to improve the performance of the construction process.
\end{abstract}

Keywords Housing, Precast Concrete, Assembly, Production

\section{Introduction}

In the construction industry, scheduling problems, delays and disputes often arise during the construction process. To avoid them, it is necessary that the knowledge of constructability reaches the project participants in advance. Designers need to be familiar with the needs of the customers, construction knowledge and how the contractor will implement the design [1-3]. The construction capacity of a design depends on a correct consideration of the limitations and possibilities of its execution [4].

Concerning construction projects, constructability is the optimal use of construction knowledge and experience during planning, design, procurement, and construction to achieve project goals [5]. It is best to review the constructability of a project in the early stages, including the design phase, to achieve a greater positive impact on its performance. Knowledge about what will be built in the early phases of the project can improve construction methods, improve decision-making and involve stakeholders in facilitating their satisfaction [6]. 
Nowadays, modern construction systems aim to produce more homes of better quality in less time [7]. Off-site construction is one of these methods that seek to optimize home construction through production based on repetition, pre-assembly and standardization. Planning and implementing an off-site construction process requires a high level of communication, coordination, and integration between developers, designers, contractors, builders, fabricators, and suppliers. The constructability of this type of housing constitutes a challenge due to the demands of pre-manufacturing [3].

During the present century, prefabricated construction grew in the economy of the Andean region, especially in prefabricated houses of diverse materials [8]. The housing deficit of Argentina (32\%), Ecuador (50\%), Venezuela (29\%) [9], Chile (13.43\%) [10], Colombia (36.6\%) [11] and Peru (10.4\%) [12], generated the need to build affordable housing for the low-income population, which can be covered through the use of PFCH [13,14]. Also, this type of housing has been used as an emergency response to disasters due to its cost, ease and speed of assembly $[13,15]$.

The demand to fill the gap between the massive supply and demand for housing has led to several $\mathrm{PFCH}$ programs being developed in countries of the region, including Colombia [16], Bolivia [17], Ecuador [18], Perú [19] Chile [20].

Despite the importance of the growing PFCH market and the permanent effort of Latin American governments to provide affordable housing to people, the literature on this construction system in the Andean countries is scarce [21]. The literature only shows the result of the implementation of the housing projects and leaves aside aspects as important as the production process, the problems and difficulties faced by those involved in these projects. Nor are any lessons learned during their development reported, which are a critical element in the management of the knowledge of constructability [1]. It is known from previous experiences that there have been problems in these constructions such as the delay in the provision by the suppliers, problems in the compatibility of the elements of different manufacturers, shortages of experienced professionals, transport problems and communication [22-26].

Even though the $\mathrm{PFCH}$ is a viable option for the countries of the Andean region, its implementation has not been evaluated nor has its production and assembly been disseminated, and less it is known the advantages and disadvantages the assembly of these houses presented in cities and in rural areas. Advantages and disadvantages thought from the point of view of production, transport and assembly on site, which are important aspects to consider for its constructability $[2,3]$.

Therefore, the objective of this research is to know the most relevant aspects in four dimensions: production methods, assembly methods, advantages and disadvantages of the PFCH that are offered in the Andean region. This information is a basic input so that the producers, the customers and the governments of the Andean region that finance housing programs can adequately evaluate the constructability of the $\mathrm{PFCH}$, the capacities they have to assemble this type of housing and prevent the difficulties that they will encounter while thinking about the production and during the assembly process.

\section{Materials and Methods}

To determine the main characteristics of production and assembly of PFCH supplied in the countries of the Andean region, the research team developed the sequential process described in Figure 1.

First, a systematic literature review was carried out through the Scopus, Web of Science (WoS) and Google Scholar databases, also including gray literature due to the scarce information in the databases. The search was carried out in the English and Spanish languages, in order to provide an analysis of publications and academic trends to evaluate the performance of existing research and understand patterns based on the following keywords: Andean region, Andean community, Peru, Venezuela, Colombia, Ecuador, Chile, Argentina, Bolivia, precast concrete, precast concrete houses, advantages, disadvantages, prefabricated housing production, precast assembly, transportation of pre-fabricated, Andean region, Andean community, precast concrete, precast concrete houses, advantages, disadvantages, precast house production, precast assembly, precast transportation. The documents were restricted outside the period 2000 - 2021, a cycle that the research team considered a time range adequate to obtain updated information regarding the subject under study. 


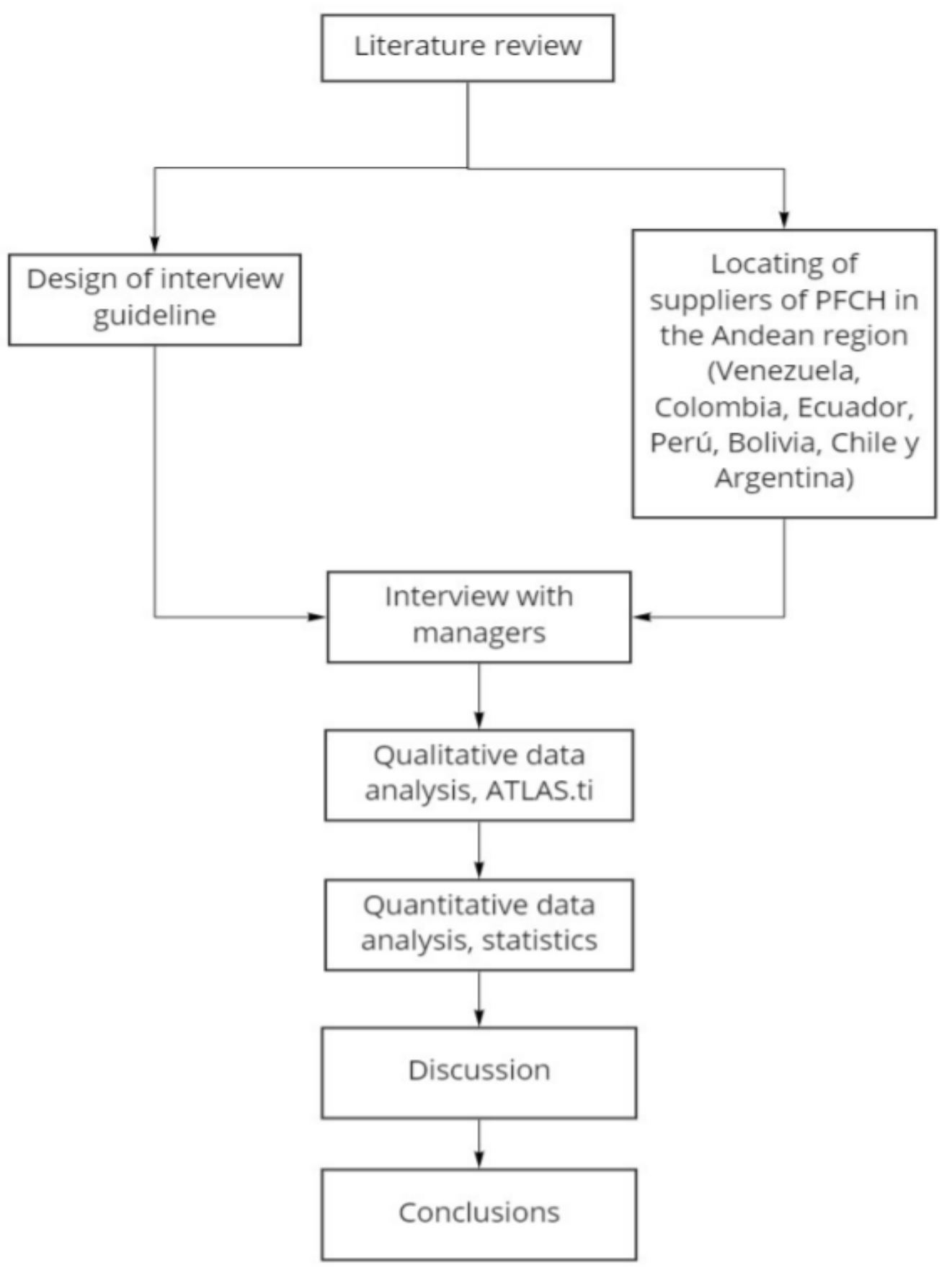

Figure 1. Methodology sequence to meet the research objectives

Second, a search was carried out for the PFCH suppliers in the Andean region, for this, the Construction Chambers of each of the countries were contacted looking for references that allow establish the existence of companies that produce or sell pre-fabricated concrete housing. Simultaneously, a search was carried out on the web pages of the PFCH suppliers, by the use of Google Chrome and Mozilla Firefox search engines, as they are considered the most used and which allow optimizing the information search process [27]. Terms such as: precast concrete, housing, construction, suppliers and builders were used to locate suppliers. Once the suppliers were located, the General or Commercial managers were contacted by mail since the research team considered them personnel with most knowledge of the production plant [28]. It was possible to locate 11 companies in the Andean region that are part of this study and are detailed in Table 1 . 
Table 1. Interview schedule

\begin{tabular}{|c|c|c|c|c|}
\hline Date & Country hour & Country & Enterprise & Interview consent \\
\hline \multirow{13}{*}{$24 / 03 / 2021$} & $12: 30$ & \multirow{2}{*}{ Argentina } & Grandio & No \\
\hline & $13: 00$ & & Vibrocom & No \\
\hline & $13: 20$ & \multirow{3}{*}{ Bolivia } & Concretec & Yes \\
\hline & $12: 30$ & & Protec & No \\
\hline & & & Grupo Gloria & No \\
\hline & $16: 00$ & \multirow{2}{*}{ Chile } & Baumax & No \\
\hline & $16: 30$ & & Faelco & No \\
\hline & $13: 00$ & \multirow{2}{*}{ Colombia } & Constructora Modularq & Yes \\
\hline & $16: 00$ & & Prefacol & Yes \\
\hline & $10: 00$ & \multirow{3}{*}{ Ecuador } & Hormypol & Yes \\
\hline & $09: 30$ & & Mutualista Pichincha & Yes \\
\hline & $16: 30$ & & Grupo Gloria & Yes \\
\hline & $17: 00$ & Perú & Grupo Gloria & No \\
\hline
\end{tabular}

Along with the location of the providers and taking into account the literature review, a semi-structured interview questionnaire (Appendant 1) was designed with open questions [29] including the objective of the research, focusing on obtaining data on the production and assembly methods used by suppliers in the Andean region, as well as knowing the advantages and disadvantages of prefabricated housing construction in this region. The interview questions were evaluated by 3 university professors, with at least 5 years of construction management experience and after their feedback a test run was carried out to fine-tune its focus.

Once the suppliers had been contacted, the interview was carried out following the schedule programmed in Table 1. The schedule of the interviews was scheduled to accommodate the time changes of each country to coincide with the working hours. The interview was carried out by means of a telephone call, which was the most appropriate means to contact those in charge because the contact numbers were available on the pages business web. The interview began with an informative introduction to the objective of the investigation, assuring each interviewee of the confidentiality of their data and requesting authorization to record it on digital media, for which a computer was used creating files in M4A sound format, which were later manually transcribed to text to facilitate analysis.

All the 11 companies were contacted, but only 6 of them (Concretec, Constructora Modularq, Prefacol, Hormypol, Grupo Gloria and Mutualista Pichincha) consented to the interview with the general managers, commercial managers or production technicians. In cases where there was no response, the information available on their web pages was used. It should be noted that of all the countries of the Andean region where less direct information was obtained was in Peru and where most information was obtained was Ecuador.

Counting on the information of the companies, the qualitative data analysis was carried out that allows researchers to draw conclusions from a set of data in textual form. This process was focused on the content analysis [30]. To facilitate the content analysis of the documents obtained from the companies, the ATLAS.ti 9 tool was used. This software was developed at the Technical University of Berlin-Germany by Thomas Murh. It has powerful tools for qualitative analysis that allow regrouping and managing the material creatively and at the same time systematically [31].

After analyzing the content of the documents, relevant terms of regularities, remarkable aspects and recurring events were categorized or codified, related to the production and construction processes of PFCH [32]. The procedure for categorization was carried out with a deductive approach, because the housing construction processes and the components that constitute it are usually known, although the assembly procedure is not exactly known [33]. In addition, to support the definition of categories, the existing literature on the matter was taken into account.

Subsequently, the categories were used to create the diagrams of networks of objects or semantic networks, which are a graphic representation in the form of nodes and interconnected arcs. Drawing the network graphs through which the information obtained from the 4 dimensions of organized way, by the use of Atlas.ti [34]. The networks were used for the analysis and interpretation of the research data, focusing on the value of the density (D) of each category, which represents the number of relationships of the indicated category with other categories [30,35]. Through this process, it was possible to identify the most important categories of production, assembly, advantages and disadvantages of PFCH. 
Table 2. Selected documents from the literature review

\begin{tabular}{|c|c|c|c|}
\hline Theme & Country & Reference & Documents \\
\hline PFCH projects & Ecuador, Colombia, Bolivia \& Chile & {$[16-18,20]$} & 7 \\
\hline PFCH production & $\begin{array}{c}\text { Argentina, Colombia, China, Chile, Spain, } \\
\text { United States \& Ecuador }\end{array}$ & {$[13-15,21,39-49]$} \\
\hline PFCH assembly & Costa Rica, Colombia, España, Perú \& & {$[46,50-55]$} & 3 \\
\hline PFCH advantages & United State, United Kingdom \& Spain & {$[43,56-58]$} & 1 \\
\hline PFCH disadvantages & $\begin{array}{c}\text { Spain, United States, China, India, } \\
\text { Malaysia, United Kingdom \& Southafrica }\end{array}$ & {$[22-26],[49,57]$} \\
\hline
\end{tabular}

Counting on the aforementioned categories, descriptive statistics were prepared based on the rooting value (E), which represents the number of times the category was mentioned by the interviewees or documents downloaded from PFCH suppliers' websites [35]. It is assumed that a greater number of mentions makes the term or category important in the subject being analyzed [36]. Also, Pareto diagrams were elaborated for the categories grouped in the dimensions of production, assembly, advantages and disadvantages, which allow a perception of the greater or lesser relevance of each category [37]. The Pareto rule allowed identifying the categories that cumulatively represent $80 \%$ of mentions, that is, the categories that are priority [38]. In this way, it was identified what is mainly important in the construction of $\mathrm{PFCH}$ according to the contacted suppliers.

As a last step, by means of a contrast between the literature and the results of the descriptive statistics, the discussion was carried out and finally the conclusions were drawn.

\section{Results}

Table 2 shows all the documents finally selected from the literature review after all the filters, where the subject to which each document is related in general is observed, the country of publication, its respective reference and it is specifically detailed how many documents refer to the Andean region.

As a result of the literature review, the relevant documents selected were 37 , of which $[16-18,20]$ are about existing projects with $\mathrm{PFCH}$ in the Andean region. Six documents refer to pre-fabricated construction in the Andean region $[13,15,21,42,43,46]$, they refer to the production of $\mathrm{PFCH}$, but none refers to the benefits and difficulties, they only relate the form of production. Three documents $[46,50,53]$ mention the assembly issue, but none details what is required for this process. Regarding the advantages of PFCH, only one document was found [49] within the Andean region, a case that was repeated with the disadvantages [49]. In total, 13 of the 37 documents refer to $\mathrm{PFCH}$ in the Andean region but do not refer to the dimensions proposed in this study.

The questionnaire that can be observed in Appendant 1 is the result of the design of the interview, which consists of 6 questions, these questions allowed to collect the necessary information to meet the objectives of the research. Questions 1 and 2 are related to the production dimension, 3 to the assembly dimension, 4 to the advantages dimension, 5 to the disadvantage dimension and question 6 was included to know the experience of each company in carrying out this type of dwellings.

For qualitative data analysis, there were 6 interviews that were transcribed, 4 videos also transcribed and 5 documents with information taken from the business web pages of the prefabricated concrete housing providers.

The categories identified from the bibliographic review as important in the prefabrication of concrete houses are shown in Table 3, where a definition and the reference of the source of said category are also shown. 
Table 3. Categories defined

\begin{tabular}{|c|c|c|}
\hline Category & Description & Reference \\
\hline Design adaptability & Ability to adapt precast elements to any design & {$[26,57]$} \\
\hline Quality & Quality of EPs & [13] \\
\hline Precast elements & Types of precast elements found on the market & {$[15,21]$} \\
\hline Production equipment & Machinery used for the production process & [25] \\
\hline Production methods & Ways of producing EPs & [49] \\
\hline Regulations & Structural and normative requirements and patents used in EPs & [46] \\
\hline Production plant & Place of production of EPs & [13] \\
\hline Concrete type & Concretes used to produce EPs & {$[45,47]$} \\
\hline Assembly equipment & Machinery used for the assembly process & [25] \\
\hline Facilities & $\begin{array}{l}\text { Facilities and fixed equipment that allow the supply and operation of the } \\
\text { services that help the dwelling to fulfill the functions for which they have been } \\
\text { designed }\end{array}$ & [45] \\
\hline Mounting methods & Ways of mounting the EPs & {$[53,54]$} \\
\hline Cost & Economic factor of the PFCH & \multirow{2}{*}{ [56] } \\
\hline Ease & Less effort for production and assembly activities & \\
\hline Transport & Equipment and trucks used to transport EPs & [22] \\
\hline Skilled labor & Personnel working at production & [45] \\
\hline Term & Designated time to carry out an activity & [57] \\
\hline Customer's perception & Customer's way of thinking about EPs & [59] \\
\hline Work order & Number of houses built with the prefabricated system & [51] \\
\hline Foundation & Basement of the house in contact with the ground & [55] \\
\hline Design & Models of PFCH & [41] \\
\hline
\end{tabular}

These categories detailed above were grouped by dimensions in 4 semantic networks, the graphs of which are presented below. In each box, a rhombus can be seen in the upper left, Figure. That identifies the box as a category. Within the box is the name of the category, the root value (E) that represents the number of citations to which each category was assigned and the value of the density (D) that represents the number of relationships of the category with other categories. The semantic networks are shown below.

\subsection{Production}

Figure 2 shows the relationships of the categories involved in the $\mathrm{PFCH}$ production process, the boxes that have a circle in the upper left part and within it horizontal lines indicate the quotes taken from the analysis texts, these were attached to the category of production equipment only in this case as an example to better clarify the origin of the $\mathrm{E}$ value of 3, the other citations with their respective categories can be found in Appendant 2.

The semantic network of Figure 2 shows 8 fundamental categories related to the $\mathrm{PFCH}$ production process. The category that stands out the most is prefabricated elements because it is related to all the remaining categories involved in the production process (which is evidenced by the value of its density D) and the least important but which was still mentioned is the type of concrete, perhaps because being precast concrete elements it is assumed that it is not relevant, however it must be considered that there may be different types of concrete and therefore it is pertinent that they have mentioned it.

\subsection{Assembly}

Figure 3 shows the relationships of the fundamental categories within the assembly process, as referred to by the interviewees and the analysis documents.

The semantic network of Figure 3 shows 7 categories involved in the $\mathrm{PFCH}$ assembly process. The most important category according to the $\mathrm{D}$ density value in this process is skilled labor due to the relationship that exists with most categories, which shows to be a key element in this process. The facilities category, although it has been mentioned, is the one with the least relationships. This does not mean that it is less important, but because the elements are prefabricated, the facilities are post-assembly. Anyway, it is an element to consider. 


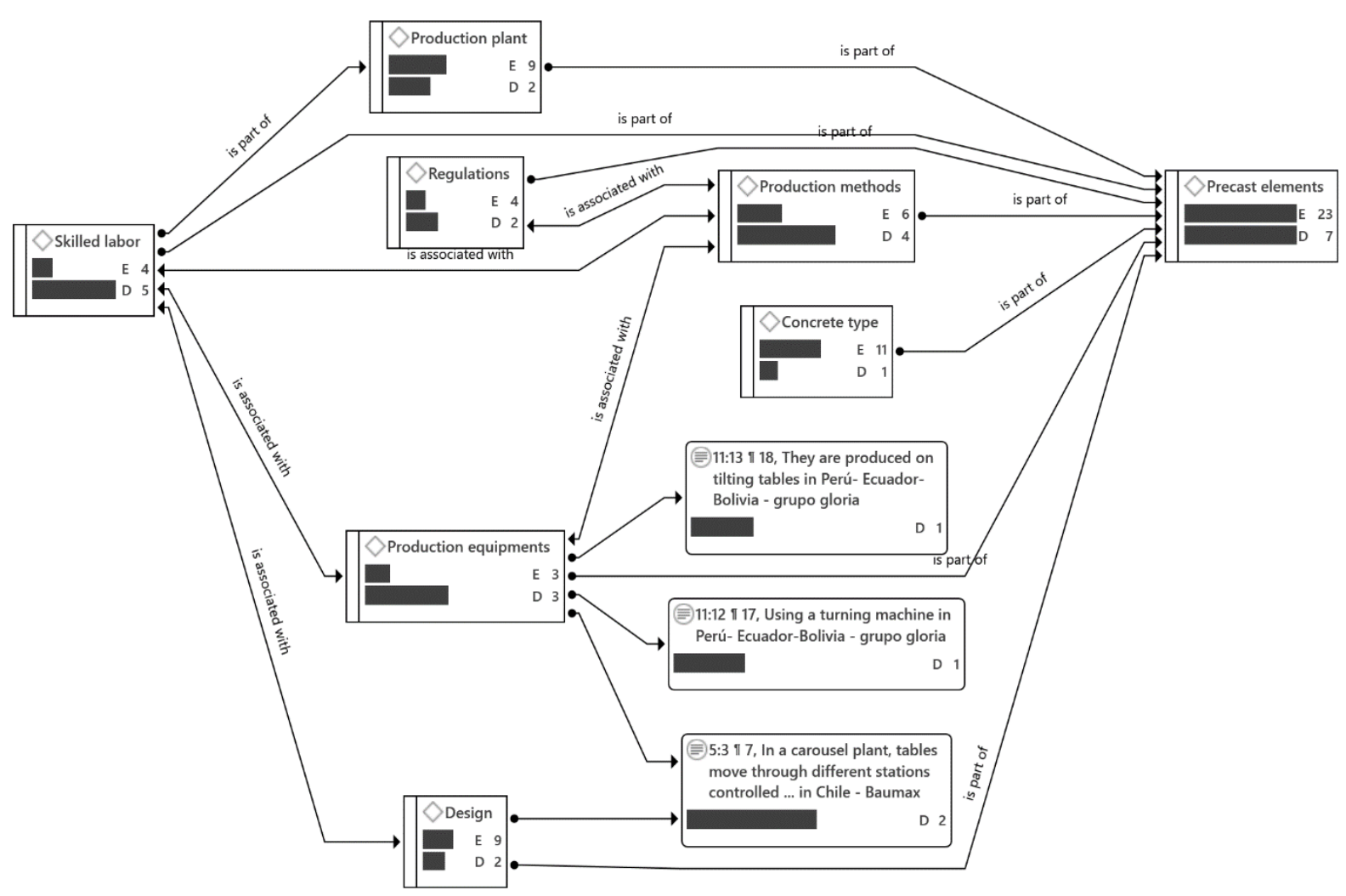

Figure 2. Key categories of the $\mathrm{PFCH}$ production process in the Andean region

is associated with

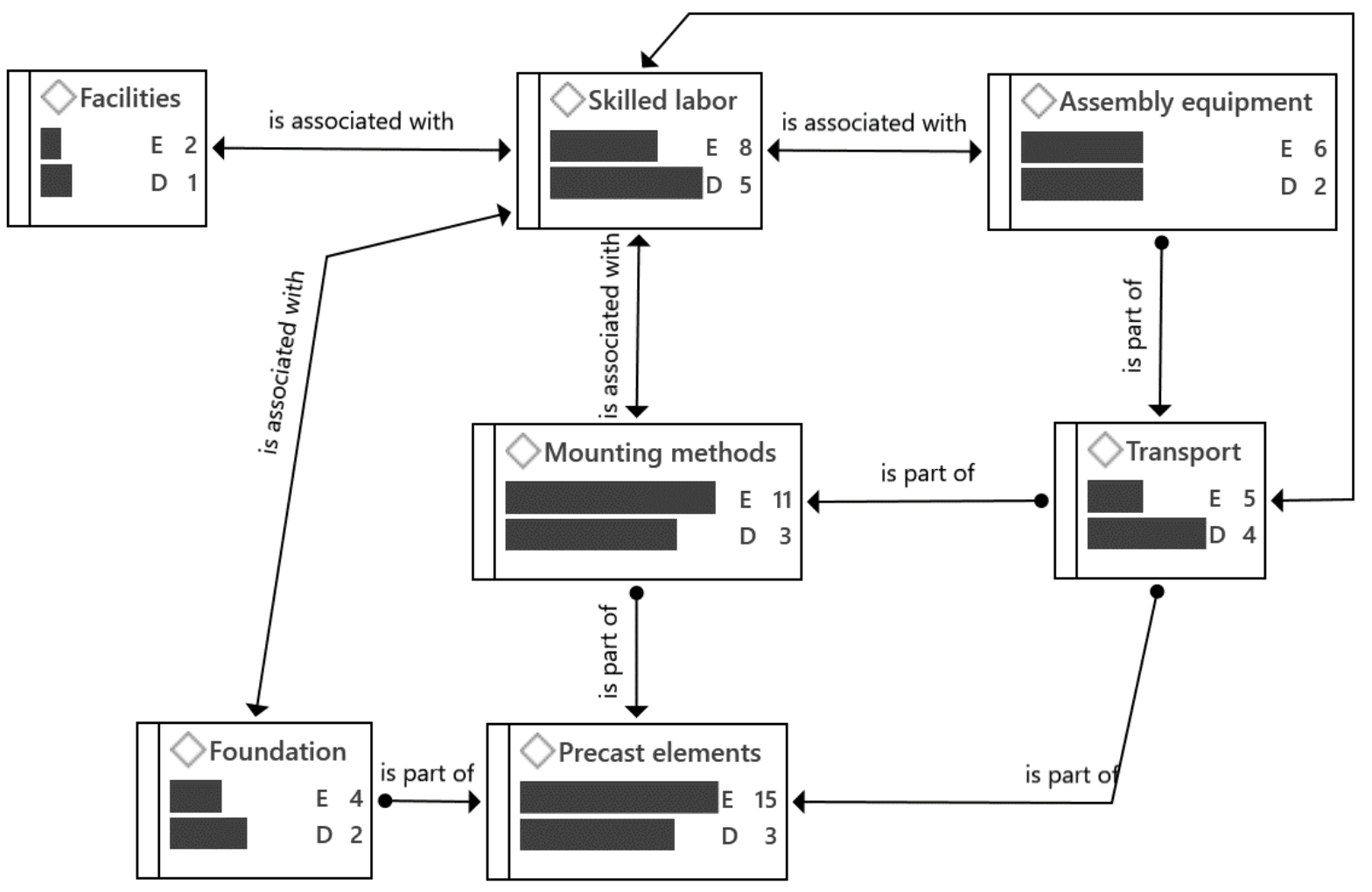

Figure 3. Fundamental categories of the $\mathrm{PFCH}$ assembly process in the Andean region 


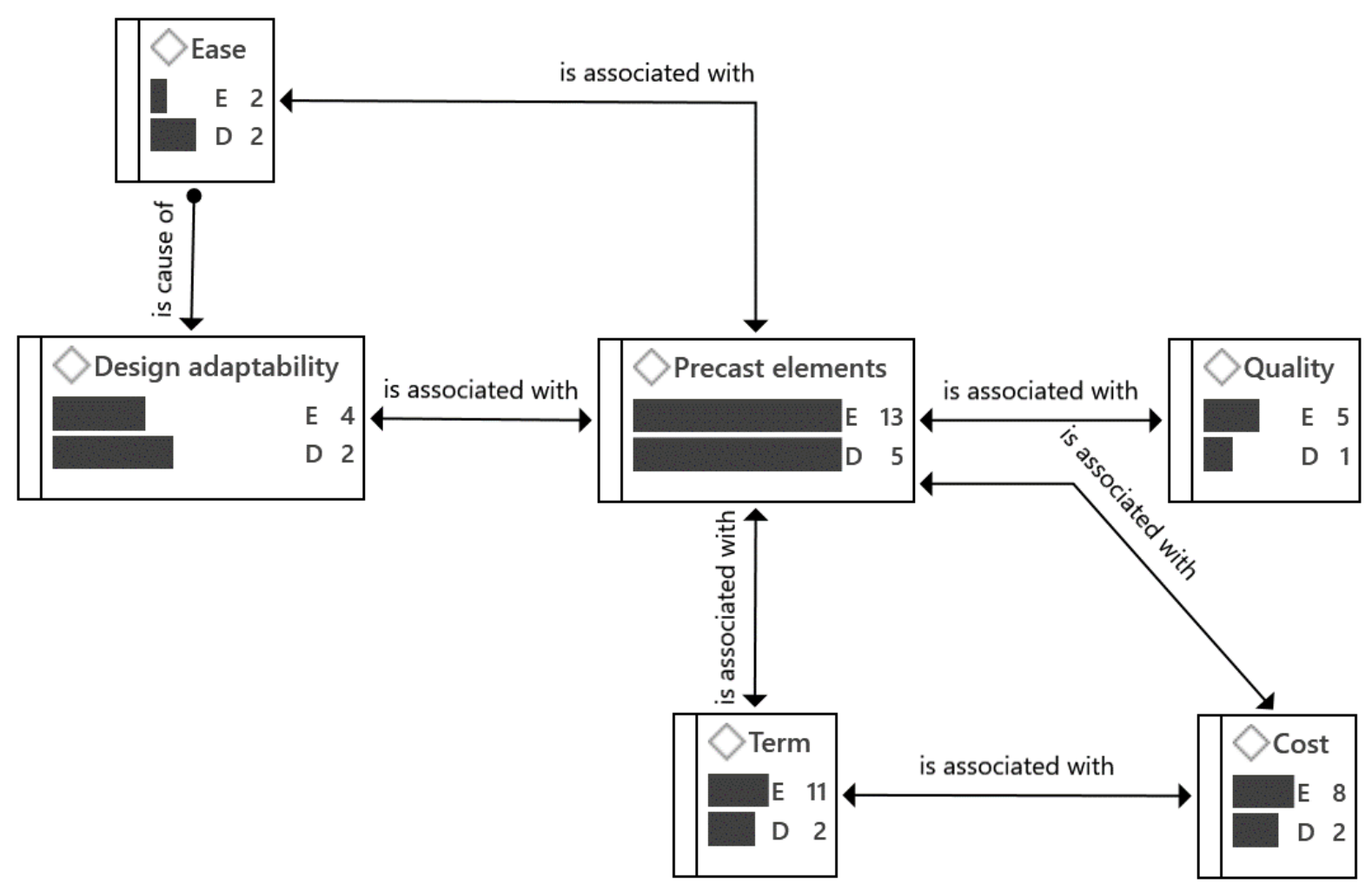

Figure 4. Key Categories of PFCH Advantages in the Andean Region

\subsection{Advantages}

Figure 4 indicates the relationships of the fundamental categories involved with the advantages of PFCH.

The semantic network of Figure 4 shows 6 categories related to the advantages of PFCH. In this network, the outstanding category for its density D is prefabricated elements. Its relationship with all the categories shows its influence on the advantages present in the houses built with this system. On the other hand, the category with the fewest relationships is quality, which is an aspect that is considered inherent to the pre-fabricated construction method but was mentioned by 5 documents.

\subsection{Disadvantages}

Figure 5 shows the relationships of the fundamental categories involved in the PFCH advantage dimension.

The semantic network in Figure 5 shows only 4 categories related to the disadvantages of the $\mathrm{PFCH}$. The most important category of the disadvantage dimension is prefabricated elements. Its relationship with all the remaining categories shows that the type of element, specifically its weight and size, influences the generation of the disadvantages. The least related category, but that has been mentioned four times, is the perception of the people. The predominant custom in the region is to work with other construction systems and traditional materials. It is well known that the construction industry is resistant to change due to the costs involved and the demand from customers.

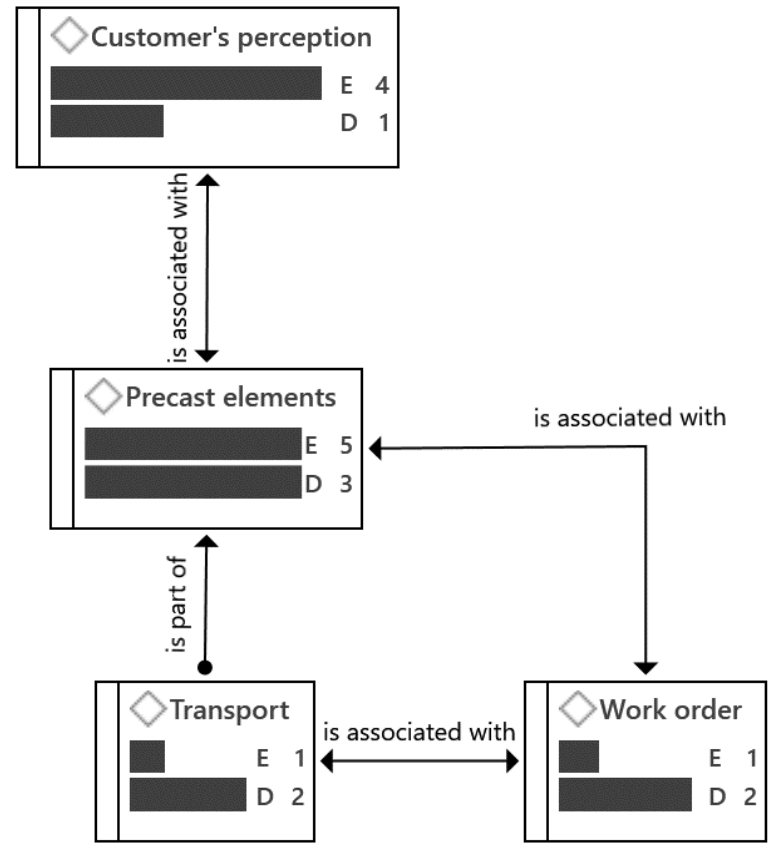

Figure 5. Fundamental Categories of $\mathrm{PFCH}$ Disadvantages in the Andean Region

After obtaining the 4 semantic networks, the rooting value (E) was taken from each category to create Pareto diagrams aiming to identify the most mentioned categories within each dimension, which are presented below. 


\subsection{Production and Assembly}

Figure 6 shows the number of citations and the cumulative percentage of the categories involved in the production and assembly process of $\mathrm{PFCH}$.

The Pareto diagrams present the 8 categories related to the production process, ranked from highest to lowest (Figure $6 \mathrm{~A}$ ) and the 7 categories related to the assembly process (Figure $6 \mathrm{~B}$ ) of $\mathrm{PFCH}$ as a function of the number of times that were cited in the analyzed documents. In the production process, $80 \%$ of the mentions were concentrated in 5 categories: precast elements, type of concrete, production plant, design and production methods with a total of 58 mentions. On the other hand, in the assembly process $80 \%$ of the mentions were concentrated in 4 categories: prefabricated elements, assembly methods, skilled labor and assembly team with a total of 40 mentions. It is observed that the central category for both processes is prefabricated elements. Skilled labor is cited more frequently in assembly process than in production, maybe because it is assumed that the workforce in the plant is trained. In any case, it is an aspect to consider in the assembly process.

\subsection{Advantages and Disadvantages}

Figure 7 shows the number of citations and the cumulative percentage of the categories involved in the advantages and disadvantages of PFCH.
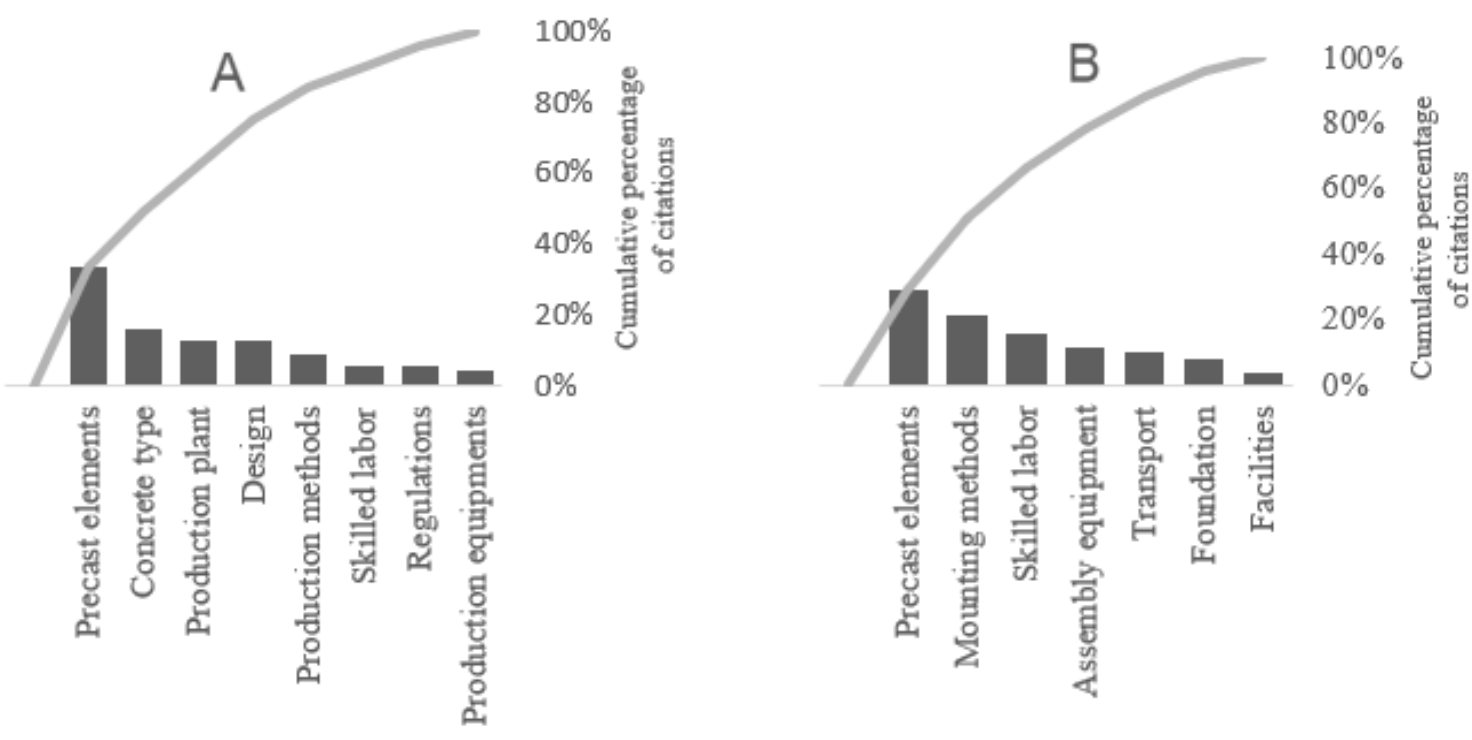

Figure 6. Pareto diagram of the production process (A) and assembly (B) of PFCH
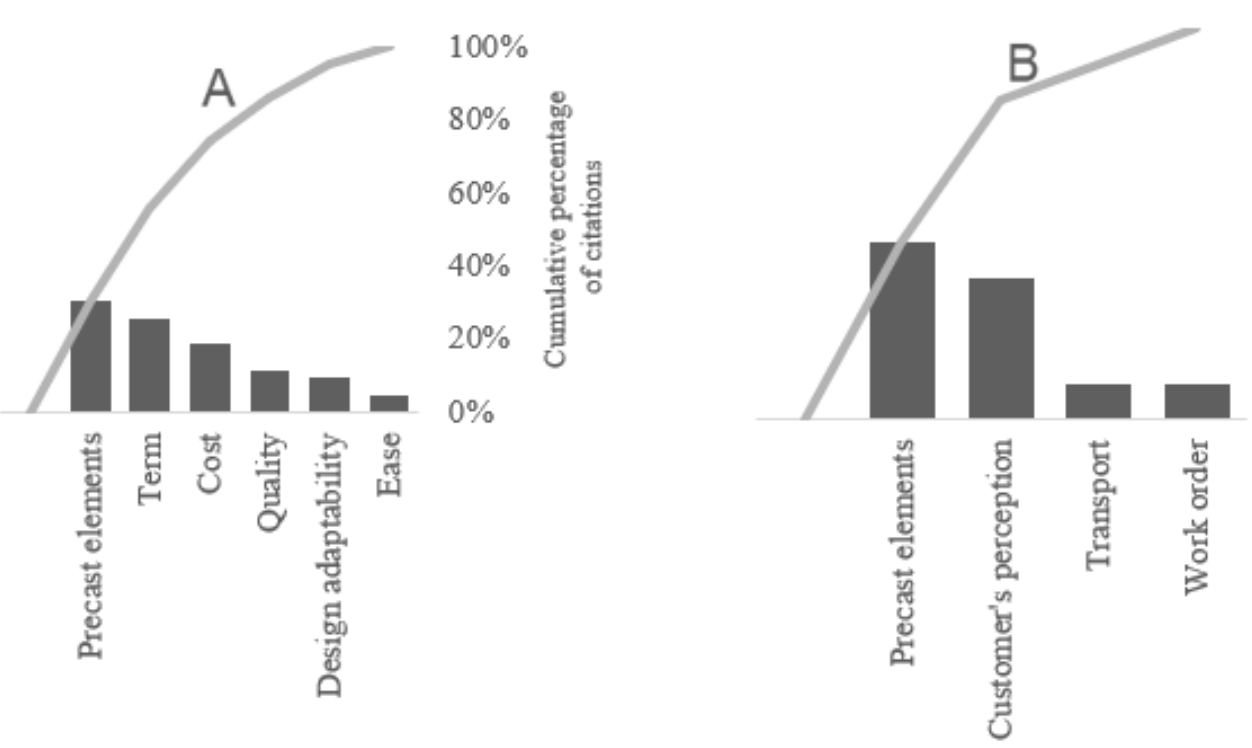

$100 \%$

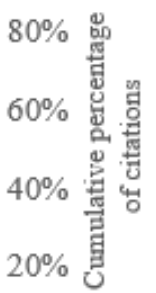

$0 \%$

Figure 7. Pareto diagram of the advantages (A) and disadvantages (B) of $\mathrm{PFCH}$ 
The Pareto diagrams in Figure 7 show in descending order the 6 categories related to the advantages and the 4 categories related to disadvantages of $\mathrm{PFCH}$, according to the number of times they were cited. It is noticed that in advantages 3 categories: prefabricated elements, term and cost are the most prominent with a total of 32 mentions. Concerning the disadvantages, the most mentions were concentrated in 2 categories, prefabricated elements, and people's perception with a total of 9 mentions. In the dimension of advantages and disadvantages, the central category is prefabricated elements. Customer's perception stands out as a disadvantage that seems to be hard to overcome even with advantages such as cost and schedule.

\section{Discussions}

In the production dimension, 8 categories were identified that are key when deciding on the PFCH (Figure 2). Of these, 4 categories are considered determining factors in the production process of the PE for housing (Figure $6 \mathrm{~A}$ ). This allows the researcher to know in more detail what the production is like and what is most important in this process. In this way, the findings of Samaniego [21], Vargas [43], Carreño [46] for prefabricated housing in the Andean region are complemented, by including aspects that are typical of the prefabrication of concrete housing.

The definition of the type of PE the PFCH will be built with is a central decision and must be taken at the beginning of the project as part of its scope, since PE conditions the concrete to be used, the capacity of the plant, the designs to be made and the methods of production.

It was established that the main method for PFCH is casting PE into formworks and only one company occupies robotic printing, confirming what was stated by Tapia [13] y Carreño [46]. These two are the main methods used in the Andean zone for PFCHs that are frequently made with reinforced concrete. Despite the advancement of the PFCH market, technological development has not followed the same trend.

For the design of the $\mathrm{PFCH}$, environmental, economic, social, transport factors must be taken into account. Considering the needs of the customer, and finally the production needs, plants are generally located off-site the construction settlement. The suppliers included in this study have the necessary production capacity, counting with equipment and formworks, most of them highlight their trained labor. According to Samaniego [21] skilled labor is indispensable because there are processes that require a good knowledge of what is being made to avoid waste and losses.

The main categories identified in the production dimensions allow the researcher to know in more detail what the production of PFCH is like and what is most important in this process. In this way, the knowledge of Vargas [49] y Carreño [41] for prefabricated housing in the
Andean region is complemented and actualized, by including aspects that are typical of the prefabrication of concrete housing.

The categories identified in the assembly dimension represent the most important aspects of this process. Our findings contribute to those of Paye et al.[53] y Carreño [41] for prefabricated housing in the Andean region. It is emphasized that the type of element defined in the production process is key in the assembly of the house. The assembly method, equipment to be used and the skilled labor involved depend on it. Skilled labor is important, as Mena [54] agrees, since it intervenes in all the activities carried out in the assembly. The experience and knowledge of the subject makes it possible to optimize the work at the same time, avoid wasting time and money, avoid accidents and reduce the work redone. The training of the workforce and their qualification for the housing assembly process is a central element that must be considered by those involved in PFCH programs in the Andean region.

For the dimension of advantages, 6 important categories were identified to consider when choosing the PFCH and three of them are considered decisive. This finding agree with Vargas [49] about the advantages of prefabricated housing in the Andean region, in a specific way for the $\mathrm{PFCH}$. The definition of the type of element that will constitute the house is a decision that will determine the presence of advantages in the prefabricated house, since it defines the speed and cost of construction. It was determined that both the schedule and the cost are going to be advantages present in all types of manufactured housing. However, this advantage increases when small and light elements are defined at the beginning, which generally facilitates the construction process.

Four are the main disadvantages identified when deciding on the PFCH (Figure 5). Two categories stand out as determinants in the disadvantages of the elements for housing. This provides in detail what disadvantages can be found when building with a precast concrete system, while confirming the findings of Vargas [49] on the disadvantages of prefabricated housing in the Andean region. As in the other dimensions already mentioned, the definition of the type of element that will be part of the prefabricated house is a central issue since the appearance of certain disadvantages in construction depends on that. However, the disadvantage of customers' perception is not directly linked to the type of element, rather it is a cultural aspect that should be considered when executing the housing programs [23].

This research on $\mathrm{PFCH}$, contributes to its constructability by facilitating knowledge that can be integrated in the design and later in the construction stage in order to achieve the project objectives by improving the performance of the construction process [6]. By providing information on those important aspects during the assembly process as well as on their advantages and disadvantages, it seeks to facilitate the design and execution stages of these projects by contributing with 
some of its limitations and execution possibilities [4]. In addition, our findings illustrate to future home customers and governments the characteristics of this construction system available in the Andean region, facilitating decision-making on $\mathrm{PFCH}$ programs, which would allow governments to achieve their objectives of improving conditions and life of their citizens through housing programs.

\section{Conclusions}

The production of PE for $\mathrm{PFCH}$, from the suppliers analyzed in the Andean region, is carried out in the plant using formworks or robotic printing (3D). They produce various precast concrete elements such as concrete panels, reinforced concrete panels, sandwich panels, self-supporting panels, wall panels, modules, beams, columns, plates, stairs and roofs. The definition of the elements that will constitute the house is the key point on which the whole process evolves. Based on this element, equipment and labor will be assigned for the execution of the prefabricated house. Thinking about constructability, designers and builders must analyze the shapes, materials and weights of these elements, so that they facilitate the transport and assembly process on site.

The common mounting method of the $\mathrm{PFCH}$ requires a concrete base foundation or platform on which the different concrete elements that make up the house are assembled. This process is carried out in two ways: with the use of a specialized assembly team that includes cranes for handling large and heavy elements; or when the elements to be assembled are of low weight, with the help of skilled labor.

Among the main advantages of PFCHs according to the analyzed providers are: cost and time reduction. Added to this is the simplicity of the construction system, the adaptability of designs and the increase in quality control. The disadvantages mentioned by the suppliers refer to: problems generated by the weight and size of the PE, problems with transportation, demand for the use of cranes and specialized labor. Furthermore, a problem associated with production is the need to build a significant quantity of PFCH for the project to be profitable for the PE producer. Given the reported disadvantages, the implementers of housing programs and builders should properly select the housing model that can be taken to the site where it will be installed.

Regarding the cost of housing and design adaptability, it was not clear whether they were advantages or disadvantages, because the opinions of the interviewees were contradictory to what was expressed in literature. Aspects that should be analyzed in future research.

A limitation of this study is that the information comes from few providers that were contacted by the research team. It is possible that there are other $\mathrm{PFCH}$ providers, national or transnational, that were not contacted due to the limited diffusion of their offer in this type of housing in the region. What could be considered as a source of a bias in the information obtained?

It is necessary to carry out a study on the constructability of the designs, the size of the PEs and their relationship with the cost of the PFCH since they are characteristics that have presented different criteria when comparing the information obtained in the literature with that obtained from the suppliers studied.

\section{Acknowledgments}

We are very grateful to experts for their appropriate and constructive suggestions to improve this paper. Also, the research team thanks the companies that provided us with the information.

\section{REFERENCES}

[1] V. Kuo and J. A. Wium, "The management of constructability knowledge in the building industry through lessons learnt programmes," Journal of the South African Institution of Civil Engineering, vol. 56, no. 1, pp. 20-27, 2014, DOI: 10.10520/EJC154142.

[2] A. A. Shash and S. Almufadhi, "Constructability: Owners, Designers, and Contractors Practices in Industrial Projects," Journal of Engineering, Project, and Production Management, vol. 11, no. 3, pp. 169-180, 2021, DOI: 10.2478/jeppm-2021-0017.

[3] X. Zhai, R. Reed, and A. Mills, "Factors impeding the offsite production of housing construction in China: An investigation of current practice," Construction Management and Economics, vol. 32, no. 1-2, pp. 40-52, 2014, DOI: 10.1080/01446193.2013.787491.

[4] L. Koskela, "Application of the new production philosophy to construction," Center for Integrated Facility Engineering, 1992.

[5] CII, "Constructability," Construction Industry Institute, https://www.construction-institute.org (accessed May. 15, 2021)

[6] S. K. I. Al-Fadhli, "Value Engineering and Constructability Assessment Relating Infrastructure Projects," IOP Conference Series: Materials Science and Engineering, vol. 737, no. 1, pp. 9-20, 2020, DOI: 10.1088/1757-899X/737/1/012040.

[7] NAO, "Using Modern Methods of Construction to Build Homes More Quickly and Efficiently," National Audit Office, 2005, https://www.nao.org.uk (accessed May. 15, 2021)

[8] CAN, "Evaluación de la dimensión económica del proceso de integración andino," Comunidad Andina, http://www.comunidadandina.org (accessed May. 18, 2021)

[9] BID, "Estudio del BID: América Latina y el Caribe encaran creciente déficit de vivienda," BID, https://www.iadb.org 
(accessed May. 09, 2021)

[10] Fundación Vivienda, "Déficit habitacional cuantitativo," Researchgate, https://www.researchgate.net (accessed May. 09, 2021)

[11] DANE, "Déficit Habitacional 2018," DANE, https://www.dane.gov.co (accessed May. 09, 2021)

[12] INEI, "Encuesta nacional de programas presupuestales," INEI, https://www.minsa.gob.pe (accessed May. 09, 2021)

[13] A. Tapia, "Iniciativa industrialización y prefabricación," Construye 2025, https://construye2025.cl (accessed May. 25, 2021)

[14] D. Fernández and J. Fernández, "Industrialización para la construcción de viviendas. Viviendas asequibles realizadas con prefabricados de hormigón," Informes de la Construccion, vol. 61, no. 514, pp. 71-79, 2009, DOI: 10.3989/ic.09.003.

[15] J. Sarmiento, "Vivienda industrializada: antecedentes en el mundo y propuesta al déficit de vivienda social en Colombia," Javeriana, vol. 10, no. 20, pp. 79-96, 2017, DOI: 10.11144/Javeriana.cvu10-20.viam.

[16] E. Chao, "Rodeo social, 500 viviendas sustentables," Construcción y tecnología en concreto, $\mathrm{http}: / /$ www.revistacyt.com.mx (accessed May. 25, 2021)

[17] La estrella del oriente, "La estrella del oriente," Santa Cruz, Sep. 21, 2013.

[18] Hormypol, "Programas de vivienda social," Hormypol, https://www.hormypol.com (accessed Apr. 15, 2021)

[19] BFT, "Modular Housing System for earthquake-proof living space in Peru," BFT Ineternational, https://www.bft-international.com (accessed Apr. 27, 2021)

[20] Instituto del cemento y del hormigón de Chile, "Industrialización y productividad," Hormigón al día, https://hormigonaldia.ich.cl (accessed May. 25, 2021)

[21] A. Samaniego, "Revisión de la industrialización de la vivienda y de tres experiencias de sistemas constructivos en Latinoamérica," Estoa, vol. 1, no. 1, pp. 23-29, 2012, DOI: 10.18537/est.001.04

[22] L. Jaillon and C. S. Poon, "The evolution of prefabricated residential building systems in Hong Kong: A review of the public and the private sector," Automation in Construction, vol. 18, no. 3, pp. 239-248, 2009, DOI: 10.1016/j.autcon.2008.09.002.

[23] C. Amoah, K. Kajimo-shakantu, and T. Van Shalkwyk, "The level of participation of the end-users in the construction of the RDP houses: the case study of Manguang municipality," International Journal of Construction Management, pp. 1-12, 2019, DOI: 10.1080/15623599.2019.1672011.

[24] D. Bandy, "Affordable Manufactured Housing Best Practices: Opportunities for California Affordable Housing Developers," California Department of Housing and Community Development, https://www.hed.ca.gov (accessed Jun. 11, 2021)

[25] A. Rahman and W. Omar, "Issues and challenges in the implementation of industrialised building systems in Malaysia," in 6th Asia-Pacific Structural Engineering and
Construction Conference, Kuala, Sep. 5-6, 2006, pp. 45-53.

[26] D. Arditi, U. Ergin, and S. Gunhan, "Factors affecting the use of prefabricated concrete system," Journal of Architectural Engineering, vol. 45, no. 6, pp. 79-86, 2000, DOI: $10.1080 / 15623599.2019 .1672011$.

[27] N. Mena Díaz, "Conferencia Pre-Congreso CNIC2015: Bibliotecarios e investigadores trabajando juntos por las investigaciones," Bibliotecas anales de Investigación, https://redib.org (accessed Jun. 19, 2021)

[28] H. Mintzberg, "La práctica gerencial," in Managing, GEN, 2010, pp. 15-17.

[29] L. Fernández, “Cómo se elabora un cuestionario?,” Bulletí LaRecerca, https://www.ub.edu (accessed Jun. 19, 2021)

[30] H. Muñoz, "Investigación cualitativa," in La investigación cualitativa Práctica desde Atlas.ti, USTA, 2016, pp. 23-25.

[31] D. Fernald, "Atlas.ti el conjunto de herramientas del conocimiento," ATLAS.ti, https://atlasti.com (accessed Jun. 20, 2021)

[32] C. Romero, "La categorización un aspecto crucial en la investigación cualitativa," Revista de Investigaciones Cesmag, vol. 11, no. 11, pp. 113-118, 2005, http://proyectos.javerianacali.edu.co/cursos_virtuales/posg rado/maestria_asesoria_familiar/InvestigacionI/Material/3 7_Romero_Categorización_Inv_cualitativa.pdf

[33] C. Díaz, "Investigación cualitativa y análisis de contenido temático. Orientación intelectual de revista Universum," General de Información y Documentación, vol. 28, no. 1, pp. 119-142, 2018, DOI: 10.5209/RGID.60813.

[34] J. M. Verd Pericás, "El uso de la teoría de redes sociales en la representación y análisis de textos. De las redes semánticas al análisis de redes textuales," Empiria Revista de metodología de ciencias sociales, no. 10, pp. 129-150, 2005, DOI: 10.5944/empiria.10.2005.1046.

[35] J. Muñoz, "Análisis cualitativo de datos textuales con Atlas/ti," Universidad autónoma de Barcelona, 2003.

[36] G. Echeverría, "Análisis cualitativo por categorías," Universidad Academia de Humanismo Cristiano, 2005.

[37] B. Rodrigues, "Diagrama de pareto," Envision, https://www.envisiontecnologia.com.br (accessed Jun. 20, 2021)

[38] B. Langerfeldt, "Cómo ser más eficiente utilizando el principio de Pareto del 80/20," Gestiopolis, www.gestiopolis.com (accessed Jun. 10, 2021)

[39] ANDECE, "Estructuras prefabricadas de hormigón," Andece, http://www.andece.org (accessed Jul. 12, 2021)

[40] BECOSAN, "Concreto Prefabricado," BECOSAN, www.becosan.com (accessed Apr. 22, 2021)

[41] A. Carreño, "Estudio de la prefabricación en concreto reforzado y su influencia en la construcción de estructuras en Colombia," Escuela Colombiana de Ingeniería Julio Garavito, 2015.

[42] CHRYSO, ¿Qué es el hormigón armado y para qué sirve?,” CHRYSO, www.chryso.es (accessed Apr. 22, 2021)

[43] F. J. Lizana Moral, A. J. Serrano Jiménez, A. Vilches Such, 
Á. Barrios Padura, and M. Molina Huelva, "Análisis de ciclo de vida y prefabricación. Evaluación del desempeño ambiental de diferentes sistemas industrializados en la edificación," Depósitp de Investigación Universidad de Sevilla, https://idus.us.es (accessed Apr. 25, 2021)

[44] A. López Vidal, A. J. Chica Paez, and V. Ramírez Collado, "Una primera aproximación a la impresión 3D: posibilidades de los materiales con base cementica," Cemento Hormigón, https://www.cemento-hormigon.com (accessed Apr. 29, 2021)

[45] J. Novas, "Sistemas Constructivos Prefabricados Aplicables a La Construccion De Edificaciones En Países En Desarrollo," Universidad Politécnica de Madrid, 2010.

[46] A. Palermo and S. Pampanin, "Analysis and Simplified Design of Precast Jointed Ductile Connections," in The 14th World Conference on Earthquake Engineering, Beijing, Oct. 12-17, 2008, pp. 1-9.

[47] G. Polat, "Factors Affecting the Use of Precast Concrete Systems in the United States," Journal of Architectural Engineering, vol. 6, no. 3, pp. 79-86, 2008, DOI: 10.1061/(asce) 1076-0431(2000)6:3(79).

[48] O. Silva, "Aprendiendo sobre aditivos para prefabricados de concreto," 360enconcreto, 2 www.360enconcreto.com (accessed Apr. 22, 2021)

[49] B. Vargas Garzón, "Industrialización de la construcción para la vivienda social," Nodo: Arquitectura. Ciudad. Medio Ambiente, vol. 2, no. 3, pp. 25-44, 2007, http://revistas.uan.edu.co/index.php/nodo/article/view/14

[50] J. Salas, "Producción, transporte y montaje," in $L a$ industrialización posible de la vivienda latinoamericana, ESCALA, 2000, pp. 127-148.

[51] V. Perdomo and F. Ruocco, "Prefabricados de Hormigón
Análisis de Sistemas Aplicados a Vivienda," Universidad de la República Uruguay, 2015.

[52] F. J. Vea, J. Pérez, E. Pellicer, and V. Yepes, "Sistema de control dimensional y de replanteo de alta precisión de elementos prefabricados singulares," Revista de la Construccion, vol. 9, no. 2, pp. 116-125, 2010, DOI: $10.4067 / \mathrm{s} 0718-915 \times 2010000200012$.

[53] A. A. Paye, J. A. Peña, and J. L. Franco, "Propuesta para la utilización de losas de entrepisos prefabricados y su evaluación costo-tiempo," Sinergia e Innovación, vol. 2, no. 2, pp. 1-29, 2014, DOI: 10.19083/sinergia.2014.376.

[54] J. M. Mena, "Optimización del montaje de estructuras prefabricadas de concreto," Instituto Tecnológico de Costa Rica, 2007.

[55] MODULAR HOME, "Los cimientos, sobre lo que descansa tu casa," Modular Home, 2017. www.modularhome.es (accessed Apr. 29, 2021)

[56] P. Muñiz, "La vivienda prefabricada en procesos de alojamiento de transición para un desplazamiento sin precedentes," Revista de investigación y arquitectura contemporánea, vol. 7, no. 7, pp. 115-134, 2017, DOI: 10.17979/bac.2017.7.0.1853

[57] K. S. Elliott and Z. A. Hamid, "Industrial Building Systems (IBS) Project Implementation," in Modernisation, Mechanisation and Industrialisation of Concrete Structures, 1 st ed, JWS, 2017, pp. 61-124.

[58] K. S. Elliott and C. Jolly, "Precast Concepts, History and Design Philosophy," in Multi-Storey Precast Concrete Framed Structures, 1 st ed, JWS, 2013, pp. 1-24.

[59] L. Garrido, "Situación actual de la construcción prefabricada en Europa," Arquitectura y construcción, https://www.interempresas.net (accessed Sep. 21, 2021) 